\title{
KEMAMPUAN CREATIVE AND CRITICAL THINKING MELALUI MODEL PEMBELAJARAN TREFFINGER DENGAN STRATEGI METAKOGNITIF UNTUK MATERI BANGUN RUANG SISI DATAR KELAS VIII SMPN 1 DAU MALANG
}

\author{
Istianah Alifia \\ SMP Negeri 1 DAU MALANG \\ Email istianahalifia@gmail.com
}

\begin{abstract}
Abstrak
Tujuan penelitian ini adalah (1) mengetahui apakah terdapat perbedaan kemampuan creative and critical thinking antara peserta didik kelas eksperimen dan kelas kontrol, (2) mengetahui mana yang lebih baik kemampuan creative and critical thinking antara peserta didik kelas eksperimen dan kelas kontrol, dan (3) mengetahui deskripsi kemampuan creative and critical thinking peserta didik kelas eksperimen. Metode penelitian yang digunakan yaitu mixed methods dengan desain sequential explanatory. Sampel dipilih melalui teknik Cluster Random Sampling diperoleh kelas VIII D sebagai kelas eksperimen dan kelas VIII E sebagai kelas kontrol sedangkan subjek penelitian dipilih dengan teknik purposive sampling, diperoleh 3 subjek yang terdiri dari 1 perwakilan padaa setiap kategori. Pengumpulan data dilakukan melalui pretest dan posttest pada tahap kuantitatif, sedangkan pada tahap kualitatif data diperoleh dari hasil wawancara dan observasi. Hasil penelitian menunjukkan bahwa (1) terdapat perbedaan yang signifikan antara kemampuan creative and critical thinking peserta didik kelas eksperimen dan kelas kontrol, (2) kemampuan creative and critical thinking peserta didik kelas eksperimen lebih baik daripada kelas kontrol, dan (3) peserta didik kelas eksperimen lebih dominan memenuhi indikator kemampuan creative and critical thinking. Tiga hasil penelitian tersebut saling mendukung.
\end{abstract}

Kata-kata kunci: pembelajaran matematika, model pembelajaran treffinger, strategi metakognitif, kemampuan creative thinking, kemampuan critical thinking.

\section{PENDAHULUAN}

Pembelajaran matematika adalah suatu upaya menciptakan kondisi yang kondusif yang ditandai dengan adanya interaksi antara peserta didik sedemikian sehingga peserta didik dapat memperoleh kompetensi terkait materi matematika yang dipelajarinya. Salah satunya kemampuan yang harus dimiliki peserta didik untuk mendukung ketercapaian tujuan pembelajaran matematika adalah kemampuan creative and critical thinking. Oleh karena itu, pembelajaran matematika harus diorientasikan pada pengembangan kognitif dengan menggunakan model dan strategi pembelajaran yang tepat.

Prinsip pembelajaran matematika tidak hanya sekadar menekankan pada learning to know, melainkan juga harus meliputi learning to do, learning to be, dan learning to live together. Dari prinsip tersebut dapat disimpulkan bahwa pembelajaran matematika ditujukan kepada peserta didik untuk tidak hanya sekedar memahami materi matematika, melainkan juga mampu menerapkan pengetahuannya dalam menyelesaikan soal matematika, bisa membuat soal, dan mampu mengajarkan apa yang diketahui kepada orang lain. Oleh sebab itu, peserta didik diarahkan untuk memahami dan menguasai konsep, dalil, teorema, generalisasi, dan teori matematika secara menyeluruh. Selain itu, peserta didik juga diharapkan dapat mengembangkan kemampuan berpikir logis, kritis, dan sistematis (Zulkarnaini, 2001:255). 
Namun, prinsip tersebut tidak berbanding lurus dengan apa yang terjadi di SMPN 1 Dau, Tegalweru, Dau, Malang. Berdasarkan hasil wawancara dengan salah seorang guru matematika kelas VIII SMPN 1 Dau, Tegalweru, Dau, Malang, Bapak Sigit Hadi Subroto, S. Pd, pada tanggal 6 Maret 2018, diperoleh dua informasi penting mengenai hal ini. Pertama, proses pembelajaran matematika di SMPN 1 Dau, Tegalweru, Dau, Malang lebih sering menggunakan model konvensional yang berpusat pada guru (teacher centered), di mana peserta didik hanya menjadi subjek pembelajaran yang pasif. Kedua, proses pembelajaran di SMPN 1 Dau, Tegalweru, Dau, Malang, belum diarahkan pada pengembangan kemampuan creative and critical thinking peserta didik.

Menyikapi permasalahan tersebut, maka perlu adanya perbaikan proses pembelajaran matematika. Salah satu upaya perbaikan kualitas pembelajaran matematika dalam melatih kemampuan creative and critical thinking peserta didik, yaitu dengan memilih model dan strategi pembelajaran yang dapat mendorong peserta didik untuk berperan aktif selama proses pembelajaran berlansung, menekankan pembelajaran berbasis masalah, serta dapat meningkatkan kemampuan creative and critical thinking peserta didik. Alternatif model dan strategi yang dapat diterapkan untuk melatih kemampuan creative and critical thinking peserta didik adalah model treffinger dengan strategi metakognitif.

Pembelajaran matematika dengan menggunakan model treffinger merupakan proses pembelajaran matematika yang menekankan pada kreativitas peserta didik dalam menyelesaikan masalah kontekstual serta kelihaian peserta didik dalam memproduksi soal. Menurut Munadar (2014:172), model treffinger adalah model yang dimaksudkan untuk menangani masalah kreativitas. Dengan melibatkan keterampilan kognitif dan afektif pada setiap tingkatnya. Pernyataan Munadar tersebut didukung oleh hasil penelitian Triwibowo dkk (2017:395) yang menunjukkan secara signifikan bahwa model treffinger efektif dalam meningkatkan kemampuan berpikir kreatif peserta didik. Model ini terdiri dari tiga langkah kegiatan, yaitu basic tools, practice with process, dan working with real problems (Huda, 2013:73).

Sedangkan yang dimaksud strategi metakognitif adalah strategi yang mengacu pada pelaksanaan dan pengontrolan aktivitas kognitif yang melibatkan penalaran peserta didik (Borich dalam Yamin 2013:30). Strategi ini terdiri dari tiga langkah kegiatan, yaitu planning, monitoring, dan evaluating (Fogarty dalam Khoiriah, 2015:178). Dengan strategi metakognitif, peserta didik dilatih untuk memahami proses berpikirnya sehingga akan lebih kritis dalam menentukan konsep atau strategi apa yang akan digunakan dalam menyelesaikan soal-soal matematika. Penelitian Maria Isabella Chrissanti dan Djamilah Bondan Widjajanti menunjukkan bahwa pembelajaran matematika dengan menggunakan strategi metakognitif lebih efektif daripada model pembelajaran konvenional dalam meningkatkan kemampuan berpikir kritis peserta didik (Chrissanti \& Widjajanti, 2015:56).

Model Pembelajaran treffinger dengan strategi metakognitif adalah model pembelajaran yang menekankan pada pengembangan creative and critical thinking dengan memerhatikan kesadaran mengenai kemampuan matematis yang dimilikinya, terlebih pada proses berpikir matematis. Sehingga, peserta didik dapat mengontrol proses berpikirnya dalam menentukan dan mempertimbangkan strategi penyelesaian masalah sekaligus bisa mengoreksi atau merefleksi letak kesalahan hasil pekerjaannya sendiri. Sintak model pembelajaran treffinger dengan strategi metakognitif dalam matematika adalah sebagai berikut.

Tabel 1: Sintaks Model Treffinger dengan Strategi Metakognitif

\begin{tabular}{|c|c|c|}
\hline \multicolumn{2}{|c|}{ Tahapan } & \multirow{2}{*}{ Kegiatan Pembelajaran } \\
\hline Treffinger & Metakognitif & \\
\hline \multirow[t]{3}{*}{ Basic tools } & Planning & $\begin{array}{l}\text { menemukan variasi cara penyelesaiannya dan kemudian } \\
\text { menyelesaikan masalah dengan strategi yang efektif }\end{array}$ \\
\hline & Monitoring & $\begin{array}{l}\text { Peserta didik melakukan monitoring akan kemampuan } \\
\text { pemahaman yang dimilikinya }\end{array}$ \\
\hline & Evaluating & $\begin{array}{l}\text { Peserta didik mengevaluasi hasil diskusi kelompok terkait } \\
\text { penyelesaian masalah tersebut }\end{array}$ \\
\hline
\end{tabular}


Lanjutan Tabel 1

\begin{tabular}{|c|c|c|}
\hline \multicolumn{2}{|c|}{ Tahapan } & \multirow{2}{*}{ Kegiatan Pembelajaran } \\
\hline Treffinger & Metakognitif & \\
\hline \multirow[t]{3}{*}{$\begin{array}{l}\text { Practice with } \\
\text { process }\end{array}$} & Planning & $\begin{array}{l}\text { Peserta didik dibimbing dan diarahkan untuk berdiskusi } \\
\text { dengan diberikan contoh analog } \\
\text { Peserta didik diminta untuk membuat masalah kontekstual } \\
\text { lengkap beserta jawabannya }\end{array}$ \\
\hline & Monitoring & $\begin{array}{l}\text { Peserta didik melakukan monitoring akan kemampuan } \\
\text { pemahaman yang dimilikinya }\end{array}$ \\
\hline & Evaluating & $\begin{array}{l}\text { Peserta didik mengevaluasi hasil diskusi kelompok terkait } \\
\text { penyelesaian masalah tersebut }\end{array}$ \\
\hline \multirow[t]{3}{*}{$\begin{array}{l}\text { Working with } \\
\text { real problems }\end{array}$} & Planning & $\begin{array}{l}\text { Peserta didik dalam kelompoknya mengidentifikasi, dan } \\
\text { mendefinisikan masalah kontekstual secara berdiskusi } \\
\text { kemudian menyelesaikan masalah tersebut }\end{array}$ \\
\hline & Monitoring & $\begin{array}{l}\text { Peserta didik melakukan monitoring akan kemampuan } \\
\text { pemahaman yang dimilikinya }\end{array}$ \\
\hline & Evaluating & $\begin{array}{l}\text { Peserta didik mengevaluasi hasil diskusi kelompok terkait } \\
\text { penyelesaian masalah tersebut }\end{array}$ \\
\hline
\end{tabular}

Berdasarkan latar belakang tersebut, maka peneliti melakukan penelitian ini yang bertujuan untuk (1) mengetahui apakah terdapat perbedaan kemampuan creative and critical thinking antara peserta didik yang diajar menggunakan model pembelajaran treffinger dengan strategi metakognitif dan model pembelajaran konvensional pada materi bangun ruang sisi datar kelas VIII SMPN 1 Dau, Tegalweru, Dau, Malang tahun pelajaran 2017/2018, (2) mengetahui mana yang lebih baik kemampuan creative and critical thinking antara peserta didik yang diajar menggunakan model pembelajaran treffinger dengan strategi metakognitif dan model pembelajaran konvensional pada materi bangun ruang sisi datar kelas VIII SMPN 1 Dau, Tegalweru, Dau, Malang tahun pelajaran 2017/2018, dan (3) mengetahui bagaimana deskripsi kemampuan creative and critical thinking peserta didik menggunakan model pembelajaran treffinger pada materi bangun ruang sisi datar kelas VIII SMPN 1 Dau, Tegalweru, Dau, Malang tahun pelajaran 2017/2018.

\section{METODE}

Penelitian ini dilaksanakan di SMPN 1 Dau, Tegalweru, Dau, Malang dengan sampel penelitian pada semester genap tahun ajaran 2017/2018, yaitu pada tanggal 7 Maret 2018 s/d 16 April 2018. Penelitian ini menggunakan pendekatan mix research dengan jenis penelitian sequential mixed methods tipe sequential explanatory design. Desain penelitian tersebut dilakukan dengan cara mengumpulkan data dan menganalisis data kuantitatif pada tahap pertama, kemudian melakukan pengumpulan data dan menganalisis data kualitatif pada tahap kedua. Selanjutnya, menganalisis data secara keseluruhan untuk kemudian mengambil kesimpulan dari tahap proses analisis data tersebut.

Penelitian tahap 1 (penelitian kuantitatif) menggunakan jenis penelitian eksperimen, yakni metode eksperimen semu (quasi experimental). Eksperimen semu merupakan jenis penelitian yang terdiri dari kelompok eksperimen dan kontrol. Akan tetapi, kelompok kontrol tidak dapat sepenuhnya mengontrol variabel-variabel luar yang memengaruhi pelaksanaan eksperimen (Sugiyono, 2016:116). Desain penelitian kuantitatif dalam penelitian ini menggunakan desain the nonequivalent pretest-posttest control group. Menurut Lestari dan Yudhanegara (2015:138) desain the nonequivalent pretest-posttest control group terdiri dari 2 kelompok, di mana sebelum dilakukan penelitian kedua kelompok diberi pretest untuk mengetahui keadaan awalnya. Selama penelitian berlangsung, kelompok pertama diberi perlakuan (X) dan kelompok yang lain tidak diberi perlakuan. Kelompok yang diberi perlakuan dijadikan kelompok eksperimen dan kelompok 
yang tidak diberi perlakuan dijadikan kelompok kontrol. Kemudian di akhir penelitian untuk mengetahui bagaimana hasilnya kedua kelompok diberi posttest. Populasi pada penelitian ini adalah peserta didik kelas VIII SMPN 1 Dau, Tegalweru, Dau, Malang sebanyak 126 peserta didik Pada tahap pertama (penelitian kuantitatif) sampel dipilih melalui teknik Cluster Random Sampling diperoleh kelas VIII D sebagai kelas eksperimen (diajar menggunakan model pembelajaran trefinger dengan strategi metakognitf) dan kelas VIII E sebagai kelas kontrol (diajar menggunakan model konvesional). Masing-masing kelas berjumlah 28 peserta didik.

Adapun teknik pengumpulan data pada tahap penelitian kuantitatif ini dilakukan dengan: (1) pretest, digunakan untuk memastikan kesamaan rata-rata kemampuan creative and critical thinking peserta didik kelas eksperimen dan kelas kontrol sebelum diberikan perlakuan, dan (2) posttest, digunakan untuk mengetahui perbedaan kemampuan creative and critical thinking peserta didik kelas eksperimen dan kontrol.

Instrumen yang digunakan dalam penelitian kuantitatif ini berupa soal pretest dan posttest kemampuan creative and critical thinking yang dikembangkan berdasarkan indikator kemampuan berpikir kreatif dan indikator kemampuan berpikir kritis. Soal pretest maupun soal posttest terdiri dari 4 butir soal uraian open-ended yang terbagi 2 butir untuk mengukur kemampuan berpikir kreatif dan 2 soal lainnya untuk mengukur kemampuan berpikir kritis.

Analisis data kuantitatif pada penelitian ini menggunakan teknik analisis data statistik inferensial. Analisis data statistik inferensial dimaksudkan untuk menganalisis data dengan membuat generalisasi pada data sampel agar hasilnya dapat diberlakukan pada populasi (Lestari \& Yudhanegara, 2015:242). Analisis data pada penelitian kuantitatif ada dua tahap yaitu (1) melakukan analisis data pretest menggunakan uji $\mathrm{t}$ dua pihak untuk mengetahui kesamaan rata-rata kedua kelas sampel, dan (2) melakukan analisis data posttest menggunakan uji t dua pihak untuk mengetahui perbandingan kemampuan creative and critical thinking peserta didik kelas eksperimen dan kontrol, kemudian dilanjutkan dengan pengujian hipotesis satu pihak kanan yang di maksudkan untuk mengetahui model manakah yang lebih efektif dalam meningkatkan kemampuan creative and critical thinking peserta didik.

Sedangkan penelitian tahap 2 (penelitian kualititatif) penelitian menggunakan jenis penelitian deskriptif kualitatif. Subjek penelitian dalam penelitian ini adalah peserta didik kelas VIII D sebagai kelas eksperimen dan VIII E sebagai kelas kontrol. Pemilihan subjek wawancara dilakukan dengan beracuan pada nilai posttest kemampuan creative and critical thinking, sehingga diperoleh 3 peserta didik. Peserta didik terpilih merupakan perwakilan dari kategori tinggi, sedang, dan rendah pada masing-masing kelas. Setiap kategori ada 1 peserta didik. Sedangkan untuk teknik observasi, dilakukan pada semua kelas kontrol dan eksperimen.

Adapun teknik pengumpulan data dilakukan dengan: (1) wawancara, dalam penelitian ini dilakukan dua kali yaitu sebelum dan sesudah diberikannya perlakuan, wawancara dimaksudkan untuk mendapatkan informasi berupa deskripsi kemampuan creative and critical peserta didik sebelum dan sesudah penelitian, (2) observasi, digunakan untuk mengamati aktivitas guru dan peserta selama proses pembelajaran berlangsung. Instrumen yang digunakan dalam penelitian ini adalah sebagai berikut: (1) pedoman wawancara, (2) lembar observasi, terdiri dari lembar observasi aktivitas guru dan lembar observasi aktivitas peserta didik. Observasi dilaksanakan selama proses pembelajaran berlangsung.

Analisis data pada penelitian kualitatif ini dilakukan dengan urutan langkah-langkah analisis sebagai berikut. (1) pengelompokkan data, (2) reduksi data, (3) penyajian data, (4) penarikan kesimpulan, dan (5) uji keabsahan data. Uji keabsahan pada penelitian ini dilakukan dengan mentriangulasi hasil observasi dari pengamat 1 dan 2 , serta membandingkan hasil wawancara dengan hasil posttest kemampuan creative and critical thinking.

Setelah mendapatkan hasil penelitian tahap pertama dan kedua, langkah selanjutnya adalah menganalisis kedua data dengan metode sequential explanatory. Analisis data kuantitatif dan kualitatif dilakukan dengan cara menelaah hubungan kedua data tersebut, apakah saling memperkuat, melengkapi, memperluas, memperdalam, atau malah bertentangan. 


\section{HASIL}

\section{Hasil Analisis Data Kuantitatif}

Hasil uji prasyarat analisis statistik data pretest maupun posttest kemampuan creative and critical thinking menunjukkan bahwa kelas eksperimen dan kelas kontrol berdistribusi normal dan mempunyai varians homogen. Sementara itu, berdasarkan hasil uji kesamaan rata-rata menunjukkan bahwa kelas eksperimen dan kelas kontrol tidak memiliki perbedaan kemampuan creative and critical thinking yang signifikan. Sementara itu, untuk hasil analisis statistik data posttest menunjukkan bahwa kelas eksperimen dan kelas kontrol berdistribusi normal, mempunyai varians homogen. Adapun hasil uji hipotesis penelitian ini, menggunakan uji t dua pihak data posttest kemampuan creative and critical thinking dengan penghitungan menggunakan software SPSS 20 ditunjukkan pada Tabel 2 berikut.

Tabel 2: Hasil Uji Hipotesis Dua Pihak

\begin{tabular}{|c|c|c|c|c|c|c|}
\hline \multirow[t]{2}{*}{ Variabel } & & \multicolumn{2}{|c|}{$\begin{array}{l}\text { Levene's Test for } \\
\text { Equality of } \\
\text { Variances }\end{array}$} & \multicolumn{3}{|c|}{ t-test for Equality of Means } \\
\hline & & $F$ & Sig. & $T$ & $D f$ & Sig (2-tailed) \\
\hline \multirow{2}{*}{ Creative Thinking } & $\begin{array}{l}\text { Equal variances } \\
\text { assumed }\end{array}$ & 0,178 & 0,674 & 2,104 & 54 & 0,040 \\
\hline & $\begin{array}{l}\text { Equal variances not } \\
\text { assumed }\end{array}$ & & & 2,104 & 53,988 & 0,040 \\
\hline \multirow{2}{*}{ Critical Thinking } & $\begin{array}{l}\text { Equal variances } \\
\text { assumed }\end{array}$ & 0,009 & 0,925 & 2,820 & 54 & 0,007 \\
\hline & $\begin{array}{l}\text { Equal variances not } \\
\text { assumed }\end{array}$ & & & 2,820 & 53,946 & 0,007 \\
\hline
\end{tabular}

Keterangan: jika Sig (2-tailed) > 0,05 berarti tidak ada perbedaan yang bermakna dan jika Sig (2-tailed) $\leq 0,05$ berarti ada perbedaan yang bermakna.

Berdasarkan penghitungan menggunakan software SPSS 20 pada Tabel 2 untuk kemampuan creative thinking diperoleh nilai sig $(2$-taled $)=0,040<0,05$. Sedangkan untuk kemampuan critical thinking diperoleh nilai sig $(2$-taled $)=0,007<0,05$. Dengan demikian, $H_{0}$ ditolak yang artinya terdapat perbedaan yang signifikan antara kemampuan creative and critical thinking peserta didik menggunakan model pembelajaran treffinger melalui strategi metakognitif dengan model pembelajaran konvensional.

Hal ini didukung oleh hasil uji t satu pihak yaitu pada uji pihak kanan yang menghasilkan penghitungan nilai $t_{\text {hitung }}=2,105841311$ untuk kemampuan creative thinking dan $t_{\text {hitung }}=$ 2,819561332 untuk kemampuan critical thinking. Dengan $d k=54$ dan taraf signifikan 0,05 maka diperoleh nilai $t_{\text {tabel }} 2,00488$. Dengan demikian jika kita bandingkan nilai $t_{\text {hitung }}$ dan $t_{\text {tabel }}$ maka diperoleh $t_{\text {hitung }}>t_{\text {tabel }}$. Artinya $H_{0}$ ditolak sehingga kemampuan creative and critical thinking peserta didik kelas eksperimen lebih baik daripada kelas kontrol.

Adapun perbandingan kemampuan creative thinking peserta didik kelas eksperimen dan kelas kontrol ditunjukkan pada diagram batang berikut.

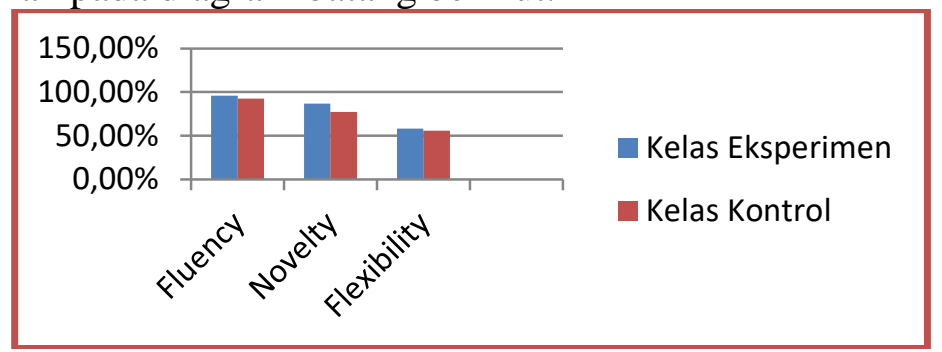

Gambar 1: Persentase Nilai Posttest Kemampuan Creative Thinking Peserta didik Kelas Eksperimen dan Kelas Kontrol 
Adapun perbandingan kemampuan critical thinking peserta didik kelas eksperimen dan kelas kontrol ditunjukkan pada diagram batang berikut.

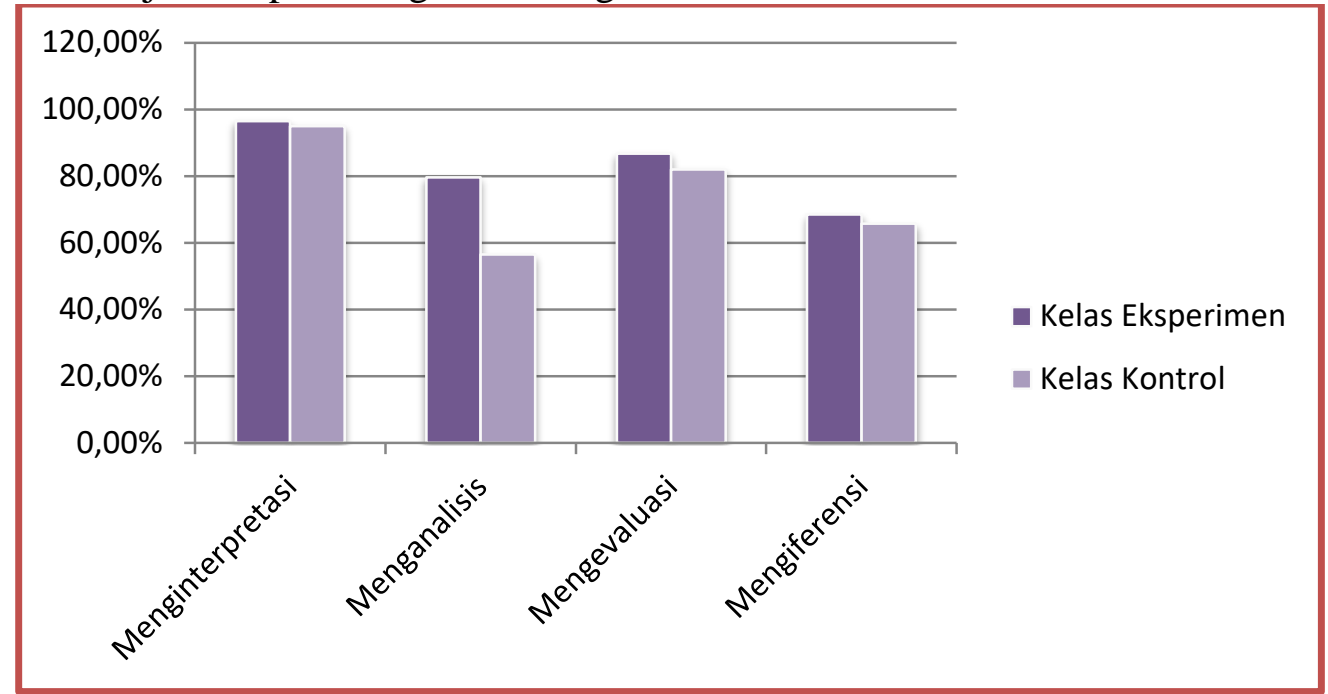

\section{Gambar 2: Persentase Nilai Posttest Kemampuan Critical Thinking Peserta didik Kelas Eksperimen dan Kelas Kontrol}

\section{Hasil Analisis Data Kualitatif}

Hasil analisis data kualitatif kemampuan creative and critical thinking sebagai berikut.

Tabel 3: Pencapaian Indikator Subjek Kelas Eksperimen dan Kelas Kontrol

\begin{tabular}{|c|c|c|c|c|}
\hline \multirow{2}{*}{ Subjek Penelitian } & \multicolumn{2}{|c|}{ Kemampuan Creative Thinking } & \multicolumn{2}{|c|}{ Kemampuan Critical Thinking } \\
\hline & Kelas Eksperimen & Kelas Kontrol & Kelas Eksperimen & Kelas Kontrol \\
\hline $\begin{array}{l}\text { Kemampuan } \\
\text { creative and critical } \\
\text { kategori tinggi }\end{array}$ & $\begin{array}{l}\text { Memenuhi indikator } \\
\text { fluency, flexibility, } \\
\text { dan novelty }\end{array}$ & $\begin{array}{l}\text { Memenuhi indikator } \\
\text { fluency, flexibility, } \\
\text { dan novelty }\end{array}$ & $\begin{array}{l}\text { Memenuhi indikator } \\
\text { menginterpretasi, } \\
\text { menganalisis, } \\
\text { mengevaluasi, dan } \\
\text { mengiferensi }\end{array}$ & $\begin{array}{l}\text { Memenuhi indikator } \\
\text { menginterpretasi, } \\
\text { mengevaluasi, dan } \\
\text { mengiferensi }\end{array}$ \\
\hline $\begin{array}{l}\text { Kemampuan } \\
\text { creative and critical } \\
\text { kategori sedang }\end{array}$ & $\begin{array}{l}\text { Memenuhi indikator } \\
\text { fluency dan novelty }\end{array}$ & $\begin{array}{l}\text { Memenuhi indikator } \\
\text { fluency dan novelty }\end{array}$ & $\begin{array}{l}\text { Memenuhi indikator } \\
\text { menginterpretasi, } \\
\text { menganalisis, dan } \\
\text { mengevaluasi }\end{array}$ & $\begin{array}{l}\text { Memenuhi indikator } \\
\text { menginterpretasi, dan } \\
\text { mengevaluasi }\end{array}$ \\
\hline $\begin{array}{l}\text { Kemampuan } \\
\text { creative and critical } \\
\text { kategori rendah }\end{array}$ & $\begin{array}{l}\text { Memenuhi indikator } \\
\text { fluency }\end{array}$ & $\begin{array}{l}\text { Tidak memenuhi } \\
\text { indikator }\end{array}$ & $\begin{array}{l}\text { Memenuhi indikator } \\
\text { menginterpretasi }\end{array}$ & $\begin{array}{l}\text { Memenuhi indikator } \\
\text { menginterpretasi }\end{array}$ \\
\hline
\end{tabular}

Hasil penelitian ini menunjukkan bahwa peserta didik kelas eksperimen lebih dominan memenuhi indikator kemampuan creative and critical thinking. Hal ini dikarenakan peserta didik kelas eksperimen lebih terlatih menggunakan kemampuan creative and critical thinking selama proses pembelajaran dibandingkan peserta didik kelas kontrol. Berikut uraian deskripsi kegiatan peserta didik kelas eksperimen selama pembelajaran.

1) Pada tahap basic tools dengan menggunakan strategi metakognitif peserta didik menyelesaikan masalah matematika open-ended

2) Pada tahap practice with process dengan menggunakan strategi metakognitif peserta didik membuat masalah matematika

3) Pada tahap working with real problem dengan menggunakan strategi metakognitif peserta didik menyelesaikan masalah matematika open-ended. 
Hasil Analisis Data Kuantitatif dan Kualitatif

Analisis data kuantitatif dan kualitatif dilakukan dengan cara membandingkan data kuantitatif dan data kualitatif terkait kemampuan creative and critical thinking. Perbandingan data ditunjukkan pada Tabel 4 dan Tabel 5 berikut.

Tabel 4: Data Kuantitatif dan Data Kualitatif Kemampuan Creative Thinking Antara Peserta Didik Kelas Eksperimen dan Kelas Kontrol

\begin{tabular}{|c|c|c|c|c|c|}
\hline \multirow[b]{2}{*}{ No. } & \multirow{2}{*}{$\begin{array}{l}\text { Indikator } \\
\text { Creative } \\
\text { Thinking }\end{array}$} & \multicolumn{2}{|c|}{ Data Kuantitatif } & \multicolumn{2}{|l|}{ Data Kualitatif } \\
\hline & & $\begin{array}{l}\text { Kelas } \\
\text { Eksperimen }\end{array}$ & $\begin{array}{l}\text { Kelas } \\
\text { Kontrol }\end{array}$ & Kelas Eksperimen & Kelas Kontrol \\
\hline 1. & Fluency & $95,82 \%$ & $92,45 \%$ & $\begin{array}{l}\text { Peserta didik mampu } \\
\text { menyelesaikan soal } \\
\text { matematika dengan } \\
\text { tepat. }\end{array}$ & $\begin{array}{lr}\text { Peserta didik mampu } \\
\text { menyelesaikan } & \text { soal } \\
\text { matematika dengan tepat. }\end{array}$ \\
\hline 2. & Novelty & $86,79 \%$ & $77,50 \%$ & $\begin{array}{l}\text { Peserta didik mampu } \\
\text { menyelesaikan soal } \\
\text { matematika open- } \\
\text { ended menggunakan } \\
\text { cara sendiri. }\end{array}$ & $\begin{array}{l}\text { Peserta didik merasa } \\
\text { kesulitan dalam } \\
\text { menyelesaikan soal } \\
\text { matematika open-ended } \\
\text { dengan cara sendiri }\end{array}$ \\
\hline 3. & Flexibility & $58,37 \%$ & $55,82 \%$ & $\begin{array}{l}\text { Peserta didik hanya } \\
\text { mampu menggunakan } \\
1 \text { cara dalam } \\
\text { menyelesaikan soal } \\
\text { matematika yang telah } \\
\text { diberikan. }\end{array}$ & $\begin{array}{l}\text { Peserta didik hanya } \\
\text { mampu menggunakan } 1 \\
\text { cara dalam menyelesaikan } \\
\text { soal matematika yang telah } \\
\text { diberikan. }\end{array}$ \\
\hline
\end{tabular}

\section{Tabel 5: Data Kuantitatif dan Data Kualitatif Kemampuan Critical Thinking Antara Peserta} Didik Kelas Eksperimen dan Kelas Kontrol

\begin{tabular}{|c|c|c|c|c|c|}
\hline \multirow[b]{2}{*}{ No. } & \multirow{2}{*}{$\begin{array}{l}\text { Indikator } \\
\text { Critical } \\
\text { Thinking }\end{array}$} & \multicolumn{2}{|c|}{ Data Kuantitatif } & \multicolumn{2}{|l|}{ Data Kualitatif } \\
\hline & & $\begin{array}{l}\text { Kelas } \\
\text { Eksperimen }\end{array}$ & $\begin{array}{l}\text { Kelas } \\
\text { Kontrol }\end{array}$ & Kelas Eksperimen & Kelas Kontrol \\
\hline 1. & $\begin{array}{l}\text { Menginterpr } \\
\text { etasi }\end{array}$ & $96,43 \%$ & $95,00 \%$ & $\begin{array}{l}\text { Dapat menuliskan apa } \\
\text { yang diketahui dan } \\
\text { ditanya yang ada pada } \\
\text { soal }\end{array}$ & $\begin{array}{l}\text { Dapat menuliskan apa } \\
\text { yang diketahui dan ditanya } \\
\text { pada soal }\end{array}$ \\
\hline 2. & Menganalisis & $79,57 \%$ & $56,43 \%$ & $\begin{array}{l}\text { Mampu membuat } \\
\text { model matematika dari } \\
\text { masalah tersebut dan } \\
\text { memberi penjelesan } \\
\text { dengan tepat }\end{array}$ & $\begin{array}{l}\text { Belum bisa membuat } \\
\text { model matematika dari } \\
\text { masalah tersebut dan } \\
\text { memberi penjelesan }\end{array}$ \\
\hline 3. & Mengevaluasi & $86,71 \%$ & $82,00 \%$ & $\begin{array}{l}\text { Mampu menentukan } \\
\text { langkah penyelesaian } \\
\text { dan memilih strategi } \\
\text { yang efektif dalam } \\
\text { menyelesaikan } \\
\text { masalah matematika }\end{array}$ & $\begin{array}{l}\text { Mampu menentukan } \\
\text { langkah penyelesaian dan } \\
\text { memilih strategi yang } \\
\text { efektif dalam } \\
\text { menyelesaikan masalah } \\
\text { matematika }\end{array}$ \\
\hline 4. & Mengiferensi & $68,42 \%$ & $65,71 \%$ & $\begin{array}{l}\text { Kurang teliti dalam } \\
\text { memberikan } \\
\text { kesimpulan dari hasil } \\
\text { yang diperolehnya. }\end{array}$ & $\begin{array}{l}\text { Kurang teliti dalam } \\
\text { memberikan kesimpulan } \\
\text { dari hasil yang } \\
\text { diperolehnya. }\end{array}$ \\
\hline
\end{tabular}

Berdasarkan Tabel 4 dan Tabel 5, dapat diketahui bahwa tidak terdapat perbedaan antara data kuantitatif dan data kualitatif. Sementara itu, berdasarkan penghitungan menggunakan software SPSS 20 diperoleh kesimpulan bahwa terdapat perbedaan yang signifikan antara kemampuan creative and critical thinking peserta didik menggunakan model pembelajaran treffinger melalui strategi metakognitif dengan model pembelajaran konvensional. Hal ini didukung oleh hasil uji t satu pihak yaitu pada uji pihak kanan yang menghasilkan kesimpulan bahwa kemampuan creative and critical 
thinking peserta didik kelas eksperimen lebih baik daripada kelas kontrol. Demikian pula dengan hasil penelitian kualitatif menunjukkan bahwa peserta didik kelas eksperimen lebih dominan memenuhi indikator kemampuan creative and critical thinking. Dengan demikian, hasil penelitian kualititatif dapat mendukung, melengkapi, dan memperkuat hasil penelitian kuantitatif yang menunjukkan bahwa persentase pencapaian indikator peserta didik kelas eksperimen yaitu 80,33\% untuk kemampuan berpikir kreatif dan 82,78\% untuk kemampuan berpikir kritis. Sedangkan persentase pencapaian indikator peserta didik kelas kontrol terbilang lebih rendah yaitu 75,26\% untuk kemampuan berpikir kreatif dan 74,78\% untuk kemampuan berpikir kritis. Dengan demikian, dapat disimpulkan bahwa model pembelajaran treffinger dengan strategi metakognitif lebih efektif dalam mengembangkan kemampuan creative and critical thinking peserta didik daripada model pembelajaran konvensional.

\section{PEMBAHASAN}

Kemampuan creative and critical thinking dalam memecahkan masalah matematika akan membekali peserta didik dengan keterampilan lain seperti keterampilan menggunakan berbagai alasan secara efektif, keterampilan berpikir secara sistematik, keterampilan mempertimbangkan dan membuat keputusan, dan keterampilan memecahkan masalah. Hal ini sesuai dengan hakikat pembelajaran matematika yang menurut Susanto (2016:186-187) merupakan proses belajarmengajar yang dibangun oleh guru untuk mengembangkan kreativitas berpikir peserta didik dan dapat meningkatkan kemampuan membangun pengetahuan baru sebagai upaya meningkatkan penguasaaan yang baik terhadap matematika.

Oleh karena itu, pembelajaran matematika harus diorientasikan pada pengembangan kemampuan creative and critical thinking peserta didik. Salah satu solusi alternatif yaitu dengan penerapan model pembelajaran treffinger dengan strategi metakognitif. Pasalnya, sebagaimana dikatakan oleh Huda (2015:318), model pembelajaran treffinger merupakan model yang berupaya mengembangkan kemampuan berpikir kreatif peserta didik dalam memecahkan masalah guna melahirkan berbagai gagasan dan menemukan solusi yang tepat untuk diimplementasikan secara nyata dengan memperhatikan fakta-fakta penting yang ada di lingkungan sekitarnya.

Untuk melengkapi sedemikian rupa sehingga sesuai dengan hakikat pembelajaran matematika sebagaimana diungkapkan oleh Susanto, model pembelajaran trefinger diimplementasikan dalam kerangka strategi metakognitif. Sebab strategi metakognitif merupakan strategi yang mengacu pada pelaksanaan dan pengontrolan aktivitas kognitif yang melibatkan penalaran peserta didik (Borich dalam Yamin, 2013:30). Dengan demikian, diterapkannya strategi metakognitif terhadap model pembelajaran trefinger akan mewujudkan hakikat pembelajaran matematika secara komprehensif, yakni tidak hanya memacu kemampuan kreativitas, tetapi juga sekaligus memacu kemampuan berpikir kritis peserta didik.

Penerapan model pembelajaran trefingger dengan strategi metakognitif diharapkan mampu melatih kemampuan creative and critical thinking peserta didik dengan memberikan keleluasaan berpikir dalam menyelesaikan masalah open-ended pada tahap basic tools, membuat masalah matematika pada tahap practice with process, dan menyelesaikan masalah konstekstual konstekstual pada tahap working with real problems. Pada setiap tahap kegiatan pembelajaran tersebut peserta didik diberikan arahan untuk menggunakan kemampuan metakognitifnya sehingga peserta didik dapat mengidentifikasi apa yang ditanya dan diketahui pada soal tersebut, dapat menentukan strategi penyelesaian apa saja yang dapat digunakan, dapat memonitoring kemampuannya dalam menyelesaikan soal tersebut, serta dapat mengevaluasi hasil penyelesaian diperolehnya dengan diskusi kelompok.

Hasil penelitian ini menunjukkan adanya perbedaan yang signifikan antara kemampuan creative and critical thinking kelas yang diberi perlakuan model pembelajaran treffinger dengan strategi metakognitif dengan kelas yang diajar dengan model pembelajaran konvensional. Secara statistik, kemampuan creative and critical thinking peserta didik menggunakan model pembelajaran treffinger dengan strategi metakognitif lebih baik daripada peserta didik yang diajar menggunakan model pembelaran konvensional. Hasil penelitian kuantitatif tersebut didukung oleh hasil penelitian 
kualititatif yang menunjukkan bahwa bahwa peserta didik kelas eksperimen lebih dominan memenuhi indikator berpikir kreatif dan berpikir kiritis.

Dari hasil uji dan analisis pada penelitian ini, dapat disimpulkan bahwa penerapan model pembelajaran treffinger dengan strategi metakognitif pada pembelajaran matematika efektif dalam mengembangkan kemampuan creative and critical thinking peserta didik. Lebih dari itu, peneliti menarik kesimpulan bahwa model pembelajaran treffinger dengan strategi metakognitif lebih mampu melejitkan creative and critical thinking peserta didik daripada model konvensional.

Hasil penelitian ini didukung oleh hasil penelitian yang ditulis oleh Triwibowo dkk (2017:395) menunjukkan bahwa model pembelajaran treffinger efektif dalam mengembangkan kemampuan creative thinking peserta didik dan hasil penelitian Chrissanti dan Widjajanti (2015:59) menunjukkan bahwa strategi metakognitif lebih efektif daripada pembelajaran konvensional dalam mengembangkan kemampuan berpikir kritis peserta didik.

\section{SIMPULAN DAN SARAN}

Berdasarkan hasil penelitian mengenai kemampuan creative and critical thinking peserta didik kelas VIII SMPN 1 Dau, Tegalweru, Dau, Malang pada materi bangun ruang sisi datar sub bahasan kubus dan balok dengan menggunakan model pembelajaran treffinger dengan strategi metakognitif, diperoleh kesimpulan sebagai berikut.

1) Terdapat perbedaan yang signifikan kemampuan creative thinking antara peserta didik kelas eksperimen dan peserta didik kelas kontrol.

2) Terdapat perbedaan yang signifikan kemampuan critical thinking antara peserta didik kelas eksperimen dan peserta didik kelas kontrol.

3) Kemampuan creative thinking peserta didik kelas eksperimen lebih baik daripada kelas kontrol.

4) Kemampuan critical thinking peserta didik kelas eksperimen lebih baik daripada kelas kontrol.

5) Peserta didik kelas eksperimen lebih dominan memenuhi indikator kemampuan creative and critical thinking. Hal ini dikarenakan peserta didik kelas eksperimen lebih terlatih berpikir kreatif dan berpikir kritis selama proses pembelajaran dibandingkan peserta didik kelas kontrol.

Berdasarkan hasil analisis data kuantitatif dan kualitatif diperoleh informasi bahwa ada perbedaan antara kemampuan creative and critical thinking antara kelas eksperimen dan kelas kontrol. Di mana kemampuan creative and critical thinking peserta didik kelas eksperimen lebih baik daripada kelas kontrol.

Berdasarkan paparan data dan pembahasan, peneliti menyarankan kepada berbagai pihak, sebagai berikut.

a) Bagi Guru

Berdasarkan hasil penelitian yang diperoleh, saran bagi guru antara lain.

1) Guru dapat menjadikan model pembelajaran treffinger dengan strategi metakognitif sebagai alternatif model yang bisa digunakan dalam upaya menciptakan pembelajaran berfokus pada peserta didik dan dapat mengembangkan kemampuan creative and critical thinking peserta didik.

2) Dalam pembentukan kelompok guru perlu memperhatikan tingkat kemampuan creative and critical thinking peserta didik sehingga dapat membentuk kelompok yang heterogen.

b) Bagi Peserta Didik

Berdasarkan hasil penelitian yang diperoleh, saran bagi peserta didik adalah sebagai berikut.

1) Selama proses pembelajaran matematika menggunakan model pembelajaran treffinger dengan strategi metakognif berlangsung hendaknya peserta didik dapat menggunakan kemampuan metakognitifnya sehingga peserta didik dapat menentukan langkah apa yang harus digunakan untuk bisa melatih kemampuan creative and critical thinking yang dimilikinya. 
2) Memahami adanya perbedaan tingkat kemampuan creative and critical thinking sehingga peserta didik lebih termotivasi lagi untuk giat dalam belajarnya, serta dapat saling melengkapi dalam mencapai tujuan pembelajaran.

c) Bagi Peneliti Selanjutnya

Berdasarkan hasil penelitian yang telah dipaparkan, peneliti selanjutnya disarankan untuk melakukan penelitian lanjutan dengan memperhatikan kekurangan pada penelitian sehingga dapat memperkuat hasil penelitian tersebut sebagai upaya meningkatkan kualitas pembelajaran matematika dalam meningkatkan kompetensi matematika peserta didik.

\section{DAFTAR RUJUKAN}

Chrissanti, M. I., \& Widjajanti, D. B. (2015). Keefektifan Pendekatan Metakognitif Ditinjau dari Prestasi Belajar, Kemampuan Berpikir Kritis, dan Minat Belajar Matematika. Jurnal Riset Pendidikan Matematika, 2(1), 51-62.

Huda, M. (2015). Model-model Pengajaran dan Pembelajaran. Yogyakarta: Pustaka Pelajar.

Khoiriah, T. (2015). Strategi Pembelajaran Metakognitif terhadap Hasil Belajar pada Konsep Sistem Pencernaan pada Manusia. Jurnal Pengajaran MIPA, 20(2), 177-180.

Lestari, K. E., \& Yudhanegara, M. R. (2015). Penelitian Pendidikan Matematika. Bandung: PT. Refika Aditama.

Munadar, U. (2014). Pengembangan Kreativitas Anak Berbakat. Jakarta: Rineka Cipta.

Sugiyono. (2016). Metode Penelitian Kombinasi (Mixed Methods). Bandung: Alfabeta.

Susanto, A. (2016). Teori Belajar dan Pembelajaran di Sekolah Dasar. Jakarta: Prenadamedia Group.

Triwibowo, Z., Dwidayati, N. K., \& Sugiman. (2017). Analisis Kemampuan Berpikir Kreatif Matematis Ditinjau dari Gaya Belajar Siswa Kelas VII Melalui Model Pembelajaran Treffinger dengan Pendekatan Open-Ended. Unnes Journal of Mathematics Education, 6 (3) 391-399.

Yamin, M. (2015). Teori dan Metode Pembelajaran. Malang: Madani.

Zulkarnaini. (2001). Strategi Pembelajaran Matematika Kontemporer. JICA: Bandung. 